\title{
Geology of the Historical Bodrogköz
}

\section{Éva Hartai}

Institute of Mineralogy and Geology

University of Miskolc, Miskolc

\section{Anna Seres}

Institute of Geography, University of Miskolc, Miskolc

\author{
Tibor Sasvári \\ Department of Mineralogy and Geology \\ Technical University Košice, Košice
}

\section{László Kuti}

Geological Institute of Hungary, Budapest

The Bodrogköz is predominantly a flat area surrounded by the rivers Tisza, Bodrog and Latorica. The Hungarian-Slovakian border cuts it into two parts; consequently, the geologic data in the two countries are different in terms of scale and in approach. The authors harmonized the different data on the two sides and created a unified geologic database for the entire area. The Bodrogköz is part of the depression at the northeastern part of the Great Hungarian Plain. It is covered mostly by Quaternary formations but in the Slovakian part there are smaller outcrops of Permian formations and Miocene volcanics.

Key words: Quaternary formations, data harmonization, geologic database

\section{Introduction}

The Bodrogköz (in Slovakian: Medzibodrožie) is situated in the northeastern part of Hungary and in the Eastern Slovakian Plain. Geographically it is bordered by three rivers: Tisza, Bodrog and Latorica (Fig. 1). The Hungarian-Slovakian border cuts this geographical unit into two main parts. The whole area covers 945 $\mathrm{km}^{2}, 556 \mathrm{~km}^{2}$ of it in Hungary; the rest is a part of Slovakia and a minor area of the Bodrogköz belongs to the Ukraine. The Bodrogköz is predominantly a flat area but in the Slovakian part volcanic cones provide variety to the landscape. Its highest point is $277 \mathrm{~m}$ (Tarbucka) and the lowest one is $93 \mathrm{~m}$ (between Kisvárda and Sárospatak).

Addresses: É. Hartai: H-3515 Miskolc-Egyetemváros, Hungary, e-mail: foldshe@uni-miskolc.hu T. Sasvári: Letná 9, 4200 Košice, Slovakia, e-mail: tibor.sasvari@tuke.sk

A. Seres: H-3515 Miskolc-Egyetemváros, Hungary, e-mail: anna_seres@yahoo.com

L. Kuti: H-1143 Budapest, Stefánia út 14, Hungary, e-mail: kutil@mafi.hu

Received: December 28, 2008; accepted: January 22, 2009 
In the framework of an INTERREG IIIA project concerning the complex landuse optimization of the entire historical Bodrogköz, the authors carried out a detailed, harmonized geologic review and created a unified geologic database. The hydrogeologic and agrogeologic conditions of the area were also considered.

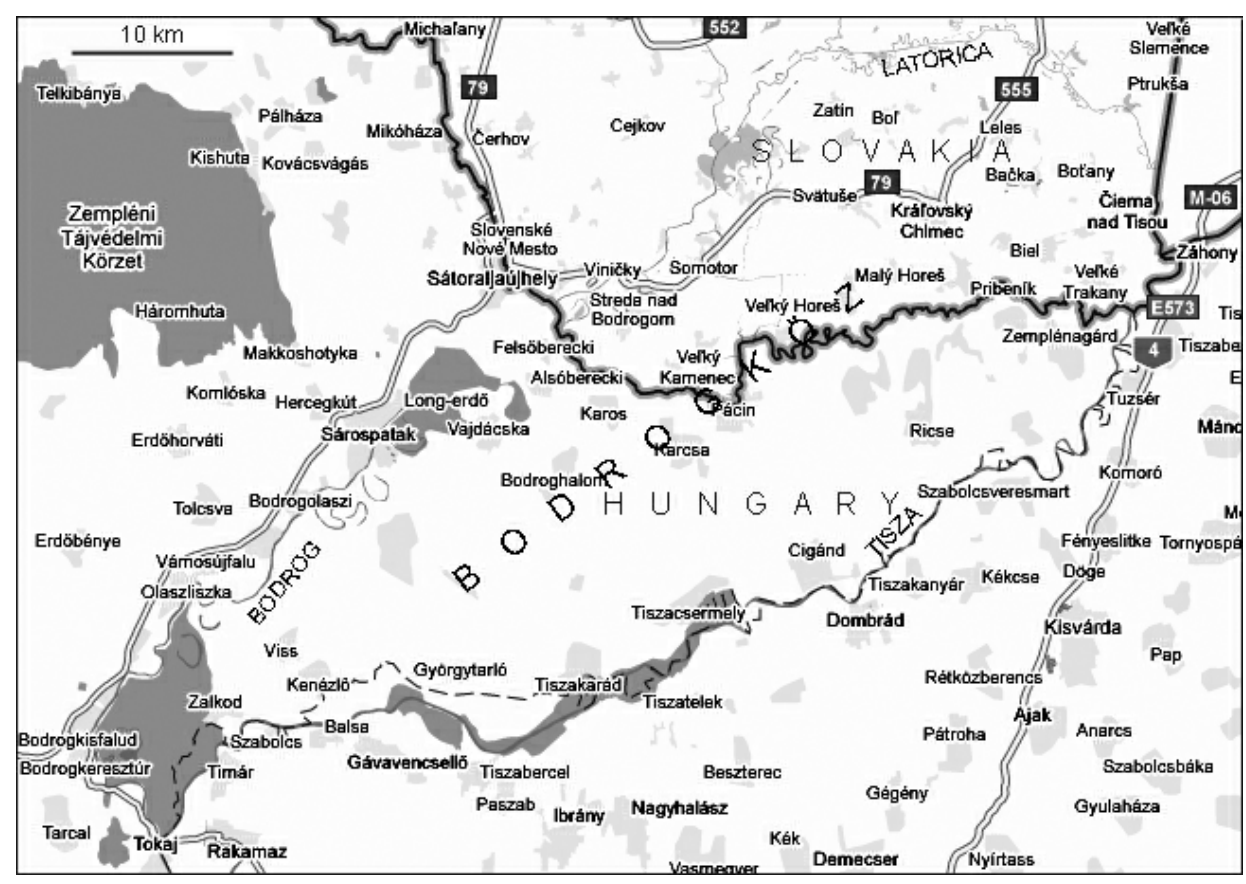

Fig. 1

Location of the Bodrogköz, bordered by the Tisza, Bodrog and Latorica

\section{Methods}

The geologic characterization of formations was based on earlier publications, with some corrections resulting from our own field observations. During the fieldwork the main problem was the lack of outcrops, as the formations are largely covered by soil and vegetation.

In the Hungarian part of the Bodrogköz the following sources were used during the outlining and characterization of the geologic formations: (1) geologic map published by Hegedús in 1952; (2) geologic map published by Borsy in 1953; (3) Geologic Map of Hungary, 1:100 000 (sheet Szerencs by Scharek 1984, sheet Sárospatak by Kuti 1998), Geological Institute of Hungary (MÁFI), Budapest, 2005, pdf format. 
In the Slovakian area the geologic examination was based on the Geologic Map of Eastern Slovakia, part Zemplín (Geologická mapa južnej casti Východoslovenskej nižiny a Zemplínskych vrchov, ed. Banacký, GÚDS, Bratislava 1989, 1:50 000, paper format).

The geologic maps were digitized and referred to a unified coordinate system by using the ArcView GIS 3.2 program. During this process the authors had to face several problems: (1) in the two countries the geological maps were made at different scales; (2) different styles were applied in the outlining of formations (detailed, indented in the Slovakian part vs. simplified in the Hungarian part); (3) the formations were not continuous at the border (in several cases the border of country was the border of geological formation); (4): the formation names were different in the two languages, (5) there were no data available from the small Ukrainian part.

In order to solve these problems the contours of the Slovakian formations were simplified, the very small fields and some similar volcanic formations were unified. The problem of formation contours along the border of the two countries was solved partly by fieldwork, partly by the logical correction of the formation contours in the map. The Slovakian formation names were translated and paralleled with the Hungarian ones. For lack of data the minor Ukrainian part of the Bodrogköz was neglected.

In the geologic database we used codes made up of a combination of letters and numbers to identify the formations. These codes characterize the origin, age and lithology of the formations.

\section{Geologic characteristics}

Formations older than Quaternary can be found only in the Slovakian part of the Bodrogköz. These are in uplifted horst structures. In the Hungarian part Sarmatian volcanics were found in boreholes. The highest position of these volcanics is at depths of 200-300 m below the surface and they are covered by Upper Pannonian then Pleistocene sediments. The maximum thickness of the Upper Pannonian sequence is $500 \mathrm{~m}$ and that of the Pleistocene is $50-100 \mathrm{~m}$ (Rónai 1985; Borsy et al. in Fehér 1988).

\section{Late Permian Cejkov sequence}

The Cejkov sequence is the oldest formation in the Bodrogköz. The older member of the sequence is a conglomerate, overlain by acidic volcanics (Boucek and Pribil 1959).

The conglomerate outcrops at Streda nad Bodrogom (Fig. 2) (in Hungarian: Bodrogszerdahely) in a $14 \mathrm{~m}$-high smaller horst. This unit contains a polymict conglomerate and purplish-red to reddish-brown shale. The conglomerate consists of well-rounded metamorphic pebbles (Grecula and Együd 1982). The 
344 É. Hartai et al.

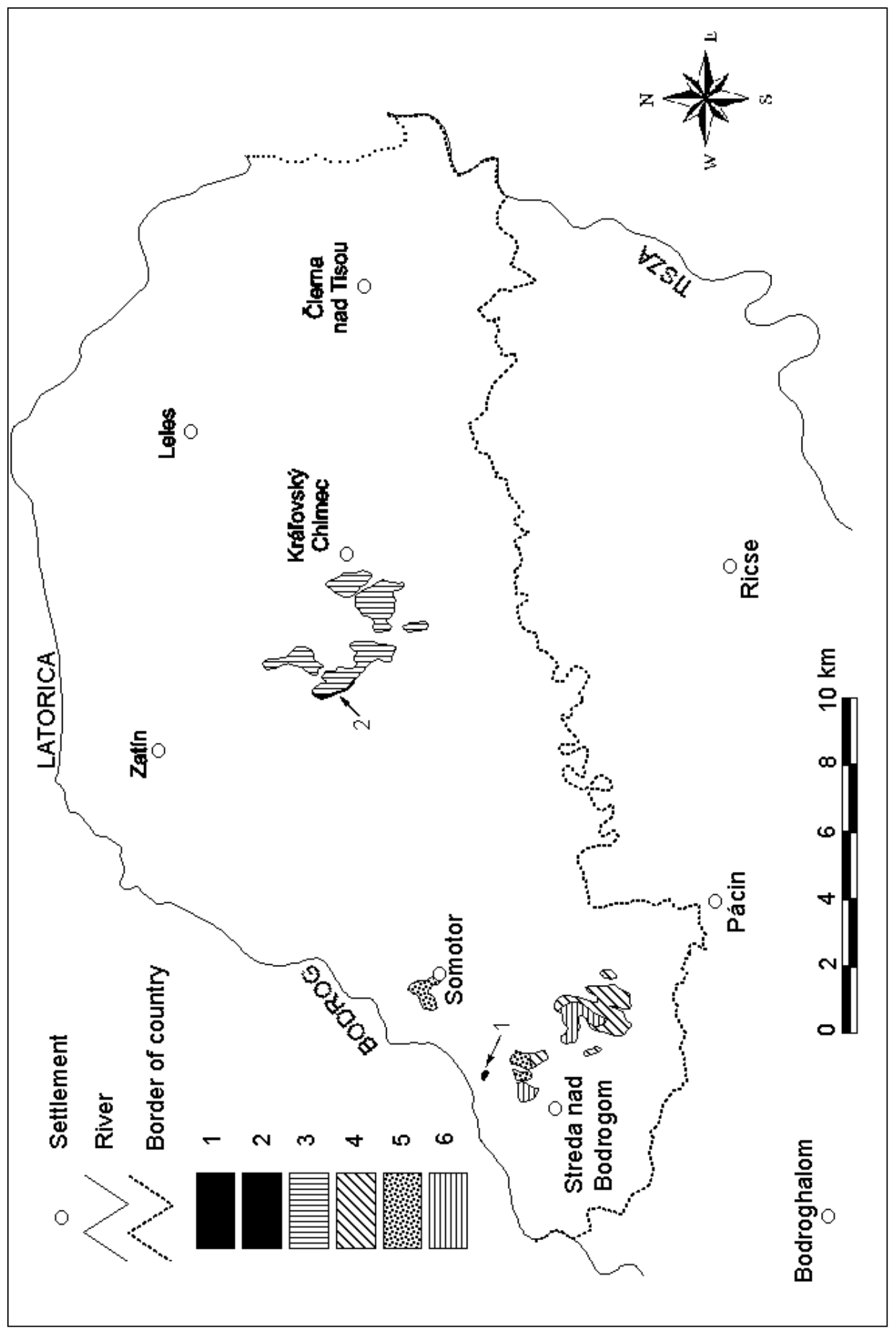

Central European Geology 51, 2008 
volcanic unit crops out at the western side of the horst in Královský Chlmec (in Hungarian Királyhelmec) (Fig. 2). It is composed of light gray rhyolitic tuff and ignimbrite.

Planderová (1981) discovered Stefanian-Autunian Vitatina and Potoniesporites microflora in the lower member of the sequence and found Jagasporites delasancei (Klaus), Taeniaesporites angulistriatus (Klaus) and Lueckisporites sp. in the upper zone. Based on this she emplaced the sequence into the early phase of the Late Permian. The maximum thickness of the Cejkov sequence is $400 \mathrm{~m}$.

\section{Neogene volcanics}

Neogene volcanic rocks occur in three horst-like structures in the Slovakian part of Bodrogköz (Fig. 2). These are situated at Královský Chlmec (the horst of Chlmec), at Streda nad Bodrogom (this is the tallest point of the area, called Tarbucka) and SW of Somotor (in Hungarian: Szomotor) - this is the horst of Vršok. The volcanics can be grouped into four types (Lexa et al. 1993):

Badenian andesitic tuffs and lava flows

This unit can be found in the horst at Královský Chlmec. It is a pyroclastlavaflow complex with a maximum thickness of $200 \mathrm{~m}$.

The lower member of the complex is reworked andesitic tuff. The rock material is well sorted; sometimes larger $(2-3 \mathrm{~cm})$ clasts occur. The reworked pyroclasts are covered by pyroxene-andesitic lava flows. Lithologically, these are hyperstheneaugite andesites, which show reddish color along the contact with the underlying pyroclasts (Banacký et al. 1989). According to the radiometric data the age of the andesite is $15 \pm 0.8$ and $15.9 \pm 0.1$ mill. years, which corresponds to the middle of the Late Badenian (Bagdasarjan 1971).

\section{Badenian rhyodacite extrusion}

The rhyodacite extrusion crops out on the southern slope of Tarbucka and in a smaller spot on the northern slope, in contact with the younger andesitic extrusion. On the southern slope, below the ruins of the medieval castle it is well exposed (Fig. 3). The light-gray/pinkish rock has a blocky structure; its texture is coarse-porphyric.

\section{Badenian andesite extrusion}

The extrusive andesite was formed at the end of the Badenian (Lexa et al. 1993). It occurs in two smaller outcrops on the northern slope of Tarbucka and in the horst of Vršok (Fig. 2). It is partly covered by Pleistocene fluvio-eolian sediments

$\leftarrow$ Fig. 2

Pre-Quarter formations of the Bodrogköz. 1. Late Permian conglomerate, 2. Late Permian acidic volcanics, 3. Badenian andesitic tuffs and lavaflows, 4 . Badenian rhyodacite extrusion, 5 . Badenian andesite extrusion, 6 . Sarmatian andesite-rhyolite complex 


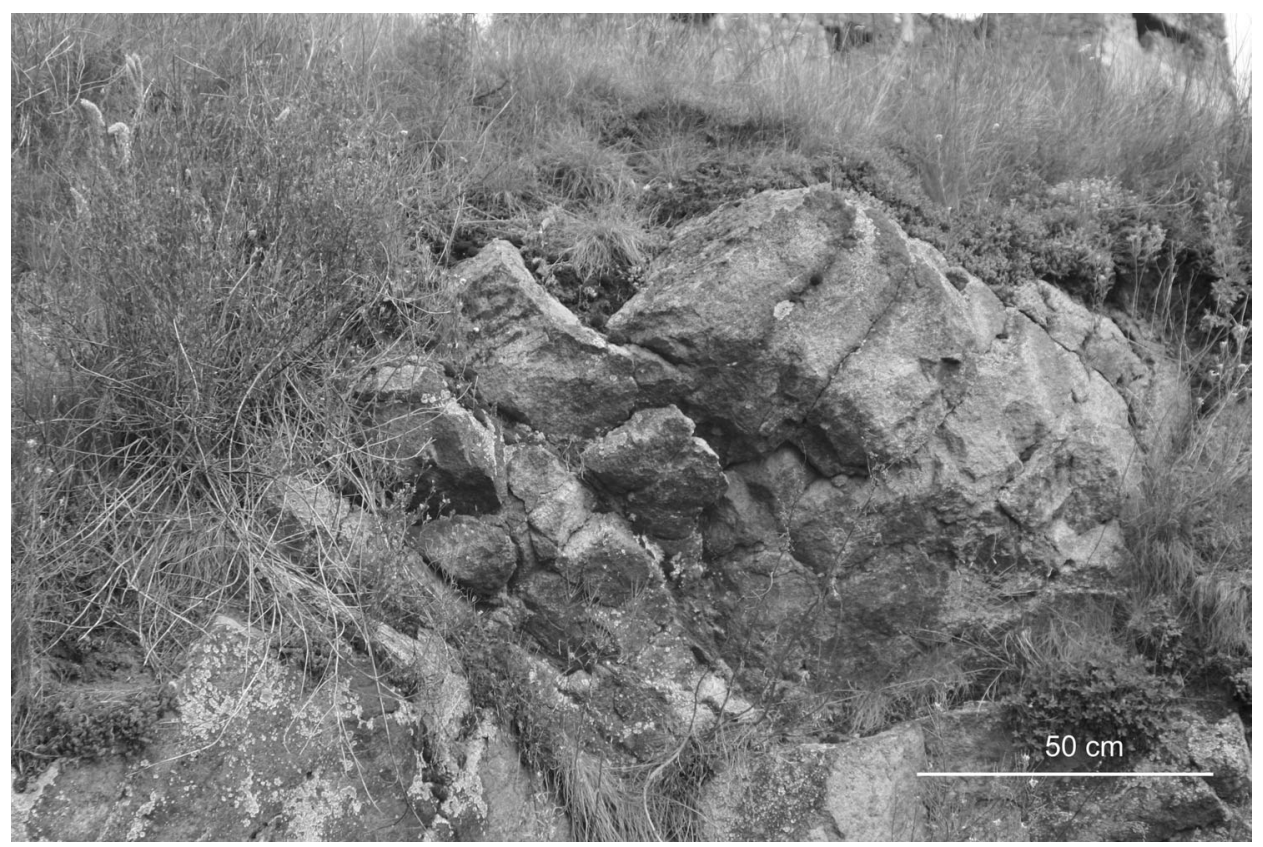

Fig. 3

Badenian rhyodacite outcrop near the ruins of the castle in Velký Kamenec

in both areas. In the peripheral parts the extrusive bodies are porous and of fluidal texture. The extrusive rocks are hypersthene-augite andesites with some accessorial amphibole, biotite and quartz.

Sarmatian andesite-rhyolite complex

Sarmatian volcanics occur only in the horst of Tarbucka (Banacký et al. 1989), (Fig. 2). In the Early Sarmatian, pyroxene-andesite lava flows and lava breccias were formed, which crop out on the top of Tarbucka. The lava flows are composed of dark gray, blocky pyroxene andesite with a limonitic-argillic alteration in the upper zones. The lava breccia is made up of dark gray, vitreous andesite, also displaying argillization. In some places the rock is strongly silicified. Chalcedony, opal and jasper occur in it, which indicates a subaquatic origin.

In the Middle Sarmatian reworked rhyolitic tuffs formed with sandstone and conglomerate intercalations. These rocks crop out at the lower end of the northwestern slope of Tarbucka.

In the Late Sarmatian basaltic andesite lava flows and hyaloclastite breccia were produced. These rocks are in contact with the Middle Sarmatian pyroclasts. Lithologically this is basaltic hypersthene-augite andesite (Banacký et al. 1989). 


\section{Pleistocene sediments}

Pleistocene diluvium

In the Bodrogköz diluvial sediments occur at the base of the eastern slope of the horst at Královský Chlmec, over an area of $0.5 \mathrm{~km}^{2}$. They were formed in the early phase of the Quaternary. They consist of unsorted, slightly rounded fragments, which are derived predominantly from volcanics. The maximum thickness of the diluvial sequence is 20 m (Banacký et al. 1989).

\section{Late Pleistocene (Early Würmian) sandy loess}

Loess sediments occur only in the Slovakian part of the Bodrogköz (Fig. 4). The sand content of the loess is about $50 \%$. This sediment can be found in the surroundings of the hills at Královský Chlmec, at Botany (in Hungarian: Battyán) and at Zatín (in Hungarian: Zétény). At Královský Chlmec it is largely covered by Holocene fluvial sediments (Banacký et al. 1989).

Late Pleistocene (Late Würmian) fluvio-eolian sand

The fluvio-eolian sand of the Bodrogköz was deposited at the end of the Würmian. Originally it probably covered a much larger area than today. It can be found in patches, usually forming smaller hills or ridges rising to $5-10 \mathrm{~m}$ above the alluvium.

The sand dunes and patches have a slight orientation: many of them are elongated in a N-S direction (Fig. 4). The thickness of the sand sequence varies from a few $\mathrm{cm}$ to $20 \mathrm{~m}$. The thickest sand layers occur in the northeastern area of the Hungarian part. In the Slovakian part larger sand patches are found on the slopes of the volcanic horsts; in other areas it forms only smaller scarps.

The dunes have a N-S strike and can be separated into two sand levels. The upper level is 1-4 m thick. It consists of well-sorted sand with thin brown and limy layers. In the lower level the sand is less well sorted and has higher carbonate content (2-4\%). Cross-bedding is characteristic mainly in the Slovakian part (Vaškovská 1974).

Mineralogically the fluvio-eolian sand consists mostly of quartz, but the proportion of dark components can reach 18-20\% (Földvári and Wallacher 1970). Among the dark minerals hypersthene, amphibole, garnet and augite are the most frequent (Horniš 1977).

In the Slovakian area the sand is frequently deposited above paludal clay. Lozek (1963) found Cochlicopa lubrica (Müll.), Vallonia costata (Müll.), Vitrea cristallina (Müll.), Perforatella bidentata (GM.) and cf. Bradybaena fruticum (Müll.) forms in a sand pit at Hrusov (in Hungarian: Körtvélyes). This fauna indicates cold climate but is characteristic for the end of the Würmian.

Concerning the origin of the fluvio-eolian sand, Hegedús (1952) and Borsy (1953) mentioned "parabolic dunes" and eolian deposition. However, they thought that there was a strong genetic relationship between the underlying "blue sand" and the "eolian" sand. The "blue sand" is a grayish blue, micaceous 


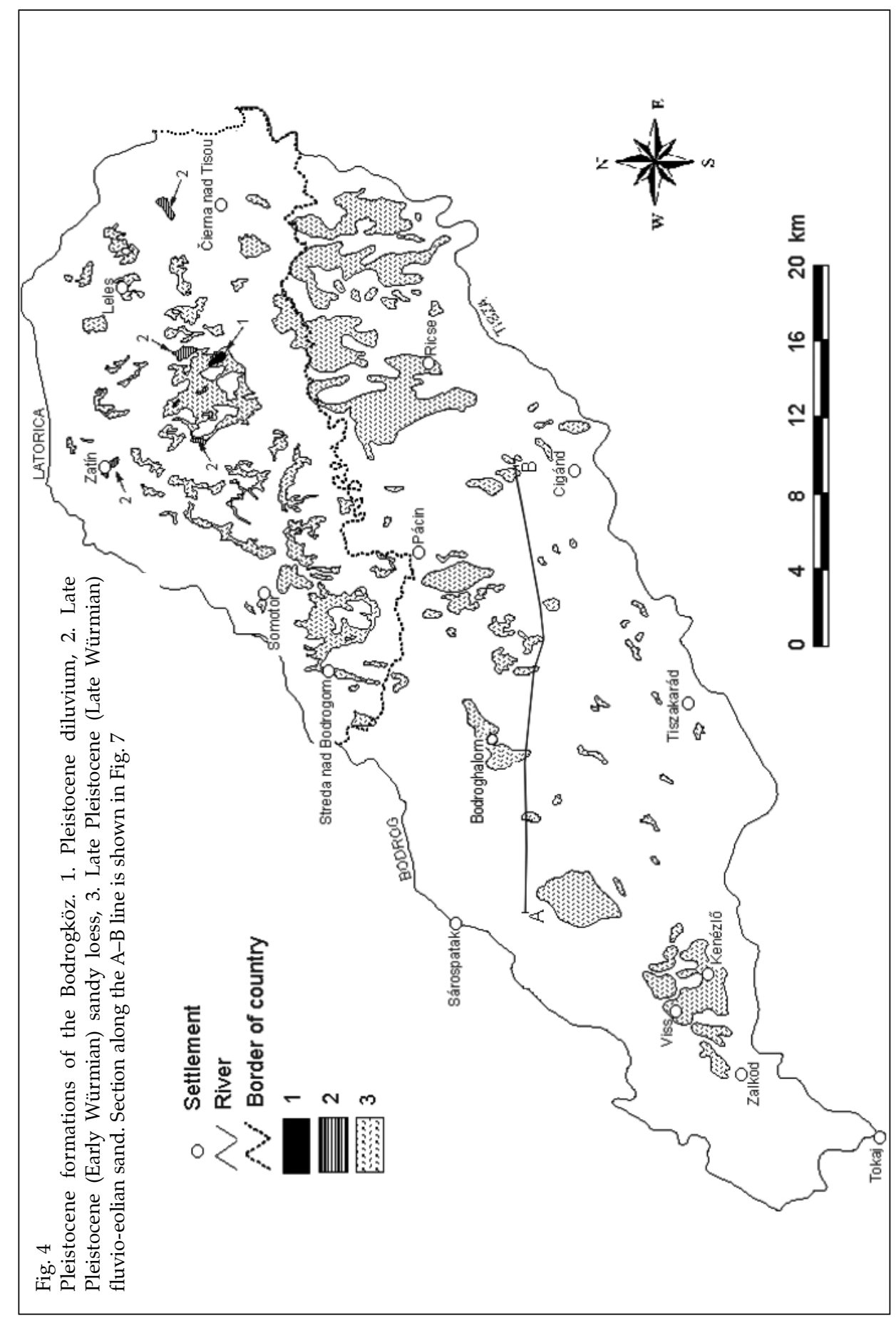

Central European Geology 51, 2008 
sand of fluvial origin, known from boreholes. The mineralogical composition of the "blue sand" and the "eolian" sand is very similar. Sümeghy (1951), Hegedús (1952) and Földvári and Wallacher (1970) assumed a short transport, as the grains of the "eolian" sand are poorly rounded and not polished. Horniš (1977) also observed that the mineralogical composition of the "eolian" sand was similar to that of the alluvium of the Tisza and Latorica.

In the 1980s several boreholes were drilled in the Hungarian part of the area, down to $30 \mathrm{~m}$. The examination of the cores proved that there continuity and mineralogical similarity existed between the dune sand and the underlying fluvial sand and sandy gravel, and that their mineralogical composition was very similar. At the end of the Pleistocene the rivers probably often changed their channel on the alluvial fan, which stretched into the recent Great Hungarian Plain. From the abandoned channels the wind blew out the fine-grained fragments. This wind-blown sand was deposited in the Nyírség as true eolian sediment. The remnants of the sand in the Bodrogköz were reworked by the wind and arranged into elongated forms, but these are not parabolic dunes. These facts indicate that the Late Pleistocene sand in the area has a fluvio-eolian origin.

\section{Holocene sediments}

Early Holocene sandy silt

The only Early Holocene formation can be found in the Hungarian part, between Pácin and Karcsa, in an area of $0.5 \mathrm{~km}^{2}$ (MÁFI 2005). From the south, two minor ranges of fluvio-eolian sand stretch into it (Fig. 5). Hegedûs (1952) and Borsy (1953) did not discuss this formation; they mentioned the area as a part of the "meadow-clay", which occurs to a large extent in the central part of the Bodrogköz. Similarly, in the northern continuation of the formation, on the Slovakian side, Holocene alluvial clay is also described (Banacký et al. 1989).

Late Holocene silty sand

In the Hungarian part silty sand occurs only in a minor outcrop at Ricse, stretching into a fluvio-eolian sand area (MÁFI, 2005). Hegedús (1952) and Borsy (1953) also plotted the formation between two "eolian" sand strips but they combined it with the young alluvial formations surrounding the river channels. On the Slovakian side the silty sand is described as the coarser-grained alluvial deposit of the Tisza. It occurs in a few minor patches in the northern part of the Bodrogköz, at Cierna nad Tisou (in Hungarian: Ágcsernyo), Královsky Chlmec (in Hungarian: Királyhelmec), Leles (in Hungarian: Lelesz) and Plešany (in Hungarian: Bodrogszentes) (Fig. 5). 


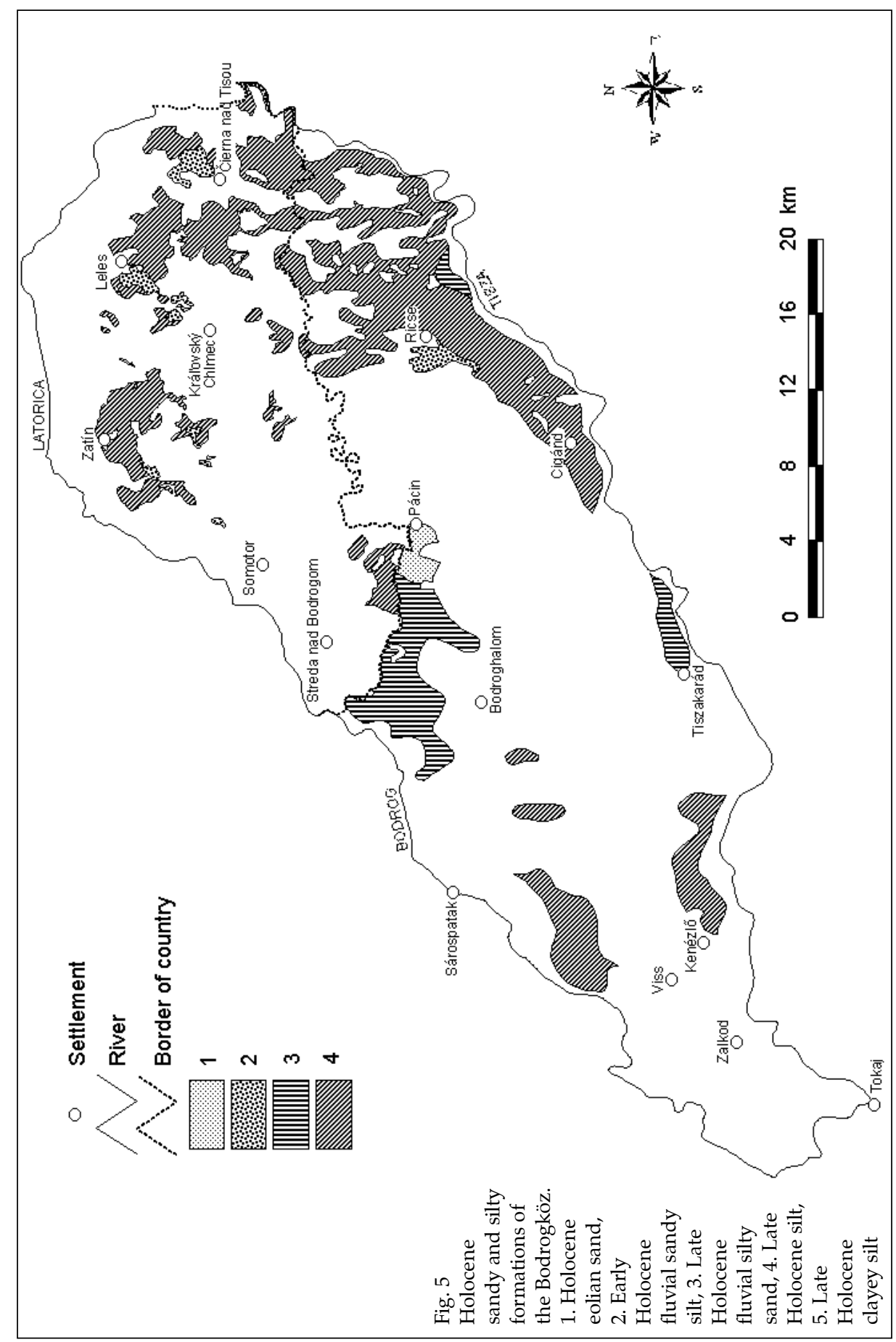

Central European Geology 51, 2008 
Late Holocene silt

On the map of the MÁFI (2005) there are two minor areas where Holocene silt can be found: one is between Tiszakarád and Tiszacsermely and the other extends from Vajdácska to Becsked. Hegedûs (1952) and Borsy (1953) did not separate this formation from the young alluvial formations. In the Slovakian part of the Bodrogköz silt is not separately mentioned (Fig. 5).

Late Holocene clayey silt

The clayey silt is special mainly in the eastern part of the Bodrogköz but it also occurs in two minor fields in the central clayey area and along the northern and southern margin of the clay (Fig. 6). Hegedús (1952 and Borsy (1953) did not separate the alluvial deposits of different grain size, they mentioned them together with the young alluvium along the rivers. In the eastern part the clayey silt is continuous on the two sides of the country border. In Slovakia it occurs in minor fields at Vojka (in Hungarian: Vajka), Trakany (in Hungarian: Tárkány), Velky Hores (in Hungarian: Nagygéres) and in the surroundings of Velky Kamenec (in Hungarian: Nagykövesd) (Banacký et al. 1989).

Late Holocene clay

The Late Holocene clay is the most widespread formation in the Bodrogköz (Fig. 6). It covers about $50 \%$ of the area. It is characteristic mainly in the central part, forming an elongated field an E-W direction (Fig. 7). Its western edge is at Bodrogkeresztúr and in the east it extends to the peat field at Nagyrozvágy. It is sediment of the flood plain with high organic matter content. In the deeper parts of the alluvial plain or in the abandoned channels black, "shiny" clay was formed. The organic matter content of this clay is $4-6 \%$. In the peripheral parts of the flood plain the clayey sequence is thinner, its color is brownish black, and the organic matter content is $1-2 \%$. Due to regular flooding, in the slowly subsiding Bodrogköz the formation of the alluvial clay was continuous until regularization of the river was carried out. The maximum thickness of the clay is $2 \mathrm{~m}$. It is deposited mainly on fluvio-eolian sand but sometimes the underlying sediment is silty clay or clayey silt.

From the boreholes at Cigánd, Bartha et al. (1987) mentions alluvial sediments beneath the clay with gradually coarser grain-size, which are deposited on the Late Pleistocene fluvio-eolian sand with a sharp contact. The clay is sometimes covered by $10-60 \mathrm{~cm}$-thick peat.

In the clay of the floodplain of Ondava, Schmidt (1974) found preboreal, thermophile Molluscae. From the borehole at Brehov he identified Valvata piscinalis (Müll.), Valvata naticina Menke, Valvata pulchella (Stud.), Lythoglypus naticoides (C. Pfr), Viviparus viviparus (L.), Sphaerium rivicola (Lam.) and Pisidium supinum A. Sch.

\section{Late Holocene peat}

The Late Holocene peat is a characteristic paludal sediment with higher than $20 \%$ organic matter content. Its thickness is $10-100 \mathrm{~cm}$. It was formed in the areas 


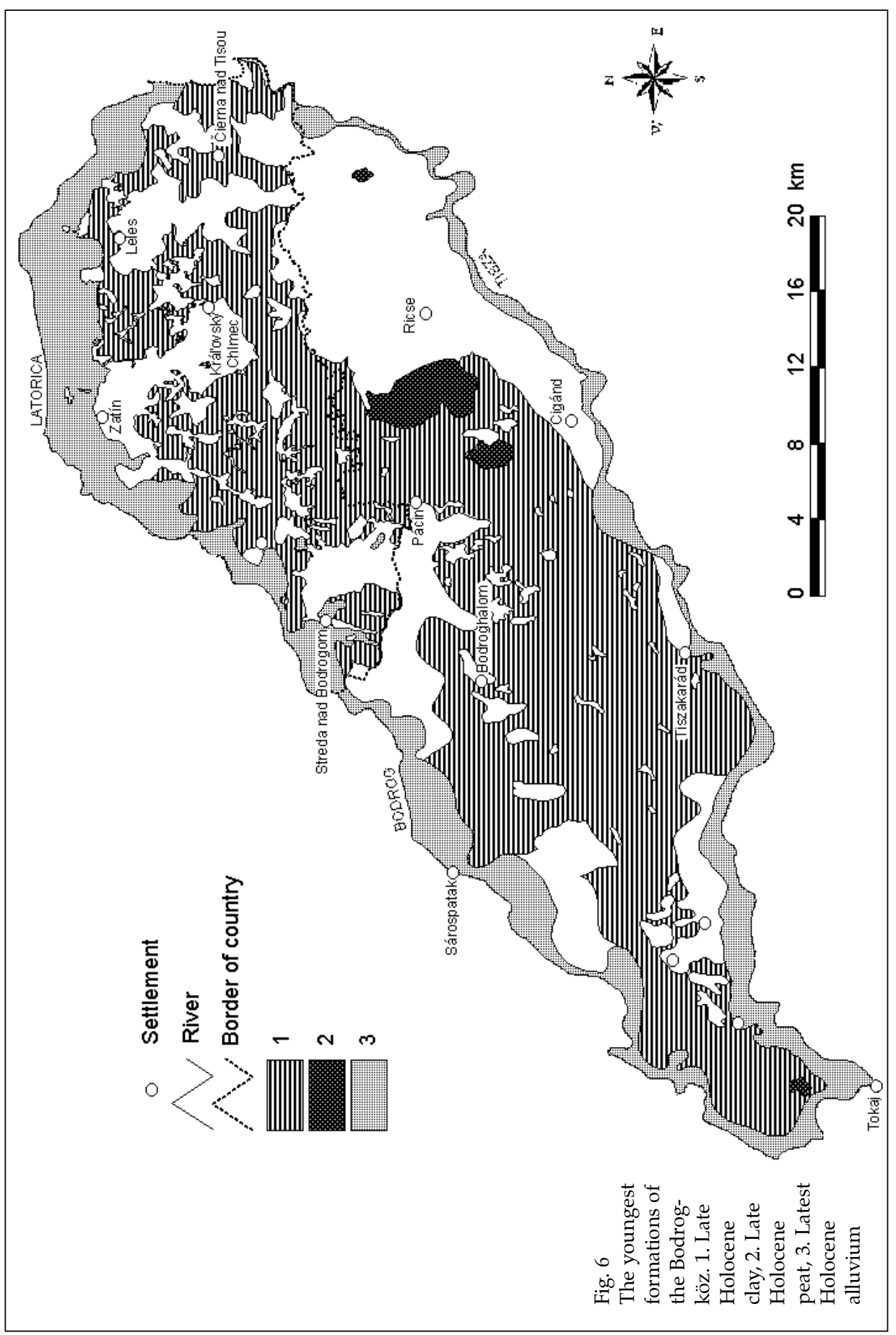

Central European Geology 51, 2008 


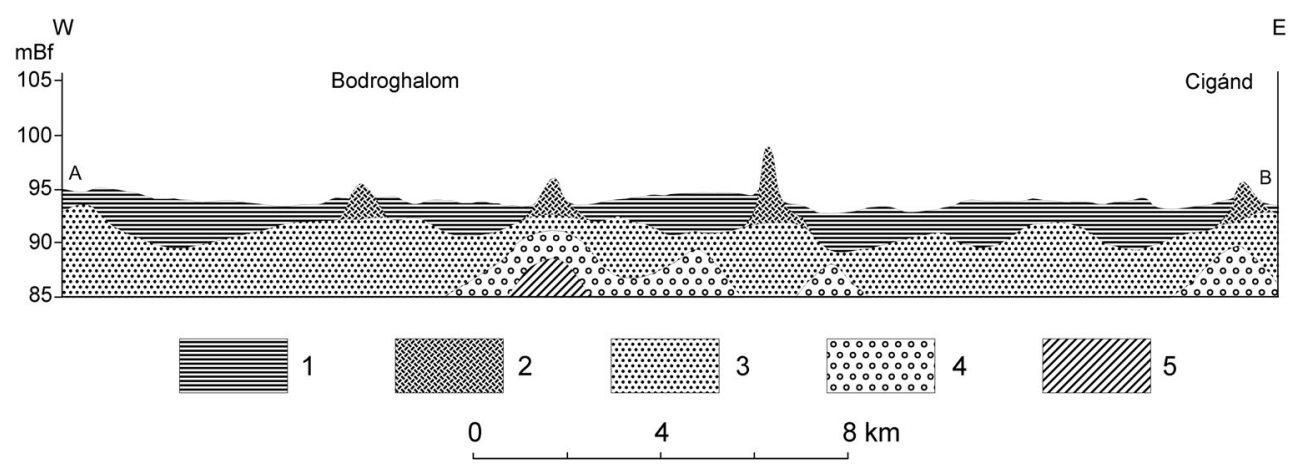

Fig. 7

Geological cross section along the A-B line indicated in Fig. 4. 1. Late Holocene alluvial clay, 2. Late Pleistocene (Late Würmian) fluvio-eolian sand, 3. Pleistocene alluvial sand, 4. Pleistocene alluvial sandy gravel, 5 . Pleistocene alluvial silt

(mostly in the Hungarian part) that were constantly covered by water. Originally it must have been occurred in a larger area but nowadays it can be found only SSW of Nagyrozvágy, at Tokaj and at Zemplénagárd. At the marginal parts of the peat areas the transition to the underlying sediments is gradual. The underlying sediments are usually alluvial clay, silt and sand (Bartha et al. 1987), but the "eolian" sand also occurs (Borsy in Fehér 1988).

In the Slovakian part the peat is found only in points, mainly at the northern margin of the horst at Královský Chlmec. According to Krippel (1971) the paleovegetation of the peat was mostly Pinus but the seeds of Betula, Almus and Quercus as well as the spores of Sphanuna are also present. In certain abandoned channels of the Tisza (e.g. at Boly) the thickness of the peat reaches 5 meters.

A large part of the peaty sediments in the Bodrogköz disappeared because they were ploughed up or destroyed by self-ignition.

Latest Holocene alluvium in general

Along the Tisza, Bodrog and Latorica young flood deposits are found in a width of $0.5-1 \mathrm{~km}$. These sediments are clay, silt, sand or a mixture thereof. The fine-grained sediments are characteristic in the levees, while the sand is particular to the convex banks. This sand is often covered by the finer-grained sediments of the younger floods.

In the flood sediments of the Latorica clay is dominant. Similarly, along the Bodrog, fine-grained sediments are characteristic (silty clay). The clay/silt ratio exceeds $80 \%$. In the young alluvium of the Tisza the rate of the coarser-grained sediments is higher, especially from Cigánd to the national boundary (Borsy in Fehér 1988). 
Földvári and Wallacher (1970) examined the flood sediments in the boreholes at the bank of the Tisza. Beneath the young deposits they even identified the Pleistocene "blue sand".

\section{Quaternary landscape evolution and tectonics}

The Bodrogköz is a young depression formed at the end of the Pleistocene and in the Holocene. Based on core examinations, for the Holocene a depression of $50 \mathrm{~m}$ was estimated in the Hungarian part. The thickness of the total Quaternary sequence in the Bodrogköz is 100-300 $\mathrm{m}$ and that of the underlying Pannonian sediments is $100-500 \mathrm{~m}$ (Rónai 1985).

In the Hungarian geomorphologic studies (Borsy 1953) the Bodrogköz and the Nyírség were assumed to be a unified area until the end of the Pleistocene, covered by eolian (in our interpretation fluvio-eolian) sand. At the end of the Pleistocene the two areas became separated; the Bodrogköz was depressed and most of the sand was removed from its surface by fluvial erosion. Even the reduced sand areas were partly covered by alluvial sediments. The Tisza River occupied its recent channel following this depression phase. The location of the junction of the Tisza and Bodrog has also changed: the one at Tokaj is relatively young.

The characteristic form of eolian sand is the blow-out dune; some of them are as long as $1 \mathrm{~km}$ in the northeastern part. The dunes rise $15-20 \mathrm{~m}$ from the alluvial plains with a NW-SE and N-S general strike.

In the Eastern Slovakian Plain Quaternary tectonics broke the area into blocks. The uplifted horsts are the Tarbucka (between Streda nad Bodrogom and Velký Kamenec), the Vršok (at Somotor) and the Chlmec horst (at Královský Chlmec). All three horsts are bordered by faults of NW-SE direction and cross-cut by faults of NNE-SSW direction. The highest horst is the Tarbucka (rises $170 \mathrm{~m}$ from the surrounding plain). The horsts are surrounded by depressions. The maximum amount of depression is estimated to be $70 \mathrm{~m}$ in the Slovakian part (Cvercko 1977 in Banacký et al. 1989).

\section{Hydrogeology}

Situation and movement of the groundwater

The Bodrogköz is rich in surface and subsurface waters. The rivers coming from the surrounding mountains often changed their channels, flooded large areas and deposited a lot of fine-grained sediments. In addition to this the water table is near the surface. As a consequence, until the time of the river regularizations the Bodrogköz was a swampy, untillable land.

The depth of the water table in the Bodrogköz is usually 1-3 m. It is less than $1 \mathrm{~m}$ only in a few deeper areas. However, in the sand dunes the water table can even be at a depth of $10 \mathrm{~m}$. In the clayey areas the groundwater is under 
pressure: after drilling through the impermeable layer the water level in the boreholes rises 1 to $2.5 \mathrm{~m}$.

Referring to the Baltic Sea level the water table in the area is between 99 and $88 \mathrm{~m}$. Its highest position is in northeast, in the fluvio-eolian sand areas, while the lowest one is in the western area, at Zalkod and Gyöngytarló. Consequently, the groundwater flows from north to south and from northeast to southwest.

The seasonal fluctuation of the water table is influenced by several factors, such as the rate of precipitation and evaporation, lithology and vegetation. Borsy et al. (in Fehér 1989) state that the fluctuation is only $60 \mathrm{~cm}$, while based on the data from the wells of VITUKI the seasonal fluctuation exceeds $2 \mathrm{~m}$.

The low permeability of the groundwater reservoir hinders or slows down the lateral movement of water and maintains the water table in a high position. This is also an addition to the formation of the inland waters.

Rónai (1985) determined 2-5 g/l salt content in the groundwater. According to his data the salts are Ca-Mg-hydrocarbonates but a significant amount of sodium, sulfate and chloride ions are also present.

Our results show that the total dissolved matter in the groundwater is below 1 $\mathrm{g} / \mathrm{l}$ in a large part of the Bodrogköz. The groundwater contains predominantly sodium-hydrocarbonates but sodium-chloride also occurs.

\section{Agrogeologic conditions}

The coarsest-grained sediments in the Bodrogköz are the Pleistocene fluvioeolian deposits. In the higher dunes (in the northeastern part) the sand is wellsorted and the amount of grains less than $0.1 \mathrm{~mm}$ in size is low. In the lower, flat dunes (at Viss, Kenézlo, Zalkod, Karos, and Karcsa) the ratio of this grain-size range reaches $20 \%$. Thus, the water balance of the latter areas is more favorable. As the amount of heavy minerals in these areas is also relatively high the fertility of these lands is better than that of the northeastern areas. In general, the soils formed on the sand are slightly humic, usually free of carbonates.

The alluvial clay, which covers extensive areas, swells by water saturation and becomes impermeable. Even in the wet seasons the water content of the clays at a depth of $60-80 \mathrm{~cm}$ is minimal. In the dry summer periods the clay shrivels up and cracks, which is also unfavorable for plant cultivation. The soil types formed on the alluvial clay are vertisols and gleysols (Dobos and Kobza 2008).

On the youngest alluvial deposits fluviosols were formed (Dobos and Kobza 2008). Due to the higher position, higher permeability and easier cultivation these areas have been the most productive fields.

The carbonate content of the near-surface layers (down to $1.5 \mathrm{~m}$ ) is an important factor in agricultural planning. In the Bodrogköz the carbonate content in this interval is generally less than $5 \%$. The most significant value $(5-30 \%)$ in the surficial layers $(0-50 \mathrm{~cm})$ occurs north of Zemplénagárd, along the national boundary. Below $0.5-1 \mathrm{~m}$ this value decreases, then increases again 
below $1 \mathrm{~m}$. North of Kisrozvágy, between $0.5-1 \mathrm{~m}$, the carbonate content is also as high as $30 \%$.

\section{Summary}

The Bodrogköz is bordered by three rivers: Tisza, Bodrog and Latorica. It can be considered as a geomorphologic and geologic unit but the HungarianSlovakian border cuts it into two main parts. The authors harmonized the data from the two countries and created a unified geologic database. A minor area of the Bodrogköz belongs to Ukraine but this part was not considered in this work as there were no available data from there.

The Bodrogköz is covered mostly by Quaternary sediments but in the Slovakian part there are some older formations. These are two minor Permian outcrops and three horsts built up by Miocene volcanics. The Pleistocene is represented mostly by fluvio-eolian sand, which forms elongated dunes. In the Holocene the most widespread sediment is alluvial clay but silty sand, silt, clayey silt and peat also occur. Along the recent river channels young alluvium has been formed.

The Bodrogköz is a young depression, which was formed in the Late Pleistocene and Holocene. The maximum thickness of the Quaternary sediments is $300 \mathrm{~m}$. In the Slovakian part block tectonics resulted in outcropping horsts.

The area is rich in surface and subsurface waters. Until the river regularizations it was a swampy, untillable land. The depth of the water table is $1-3 \mathrm{~m}$. The amount of dissolved matter (mostly sodium-hydrocarbonates, lesser sodiumchlorides) in the groundwater is usually below $1 \mathrm{~g} / \mathrm{l}$. The carbonate content of the near-surface sediments varies between a few percent to $30 \%$.

\section{References}

Bagdasarjan, G.P. 1971: Chronostratigrafický a biostratigrafický vek niektorých významných vulkanitov v. Slovenska (The chrono- and biostratigraphic data of some East-Slovakian volcanites). - Geol. Práce, Správy 58, Geol. úst. D. Stúra, Bratislava, pp. 87-96 (In Slovakian.)

Banacký, V., M. Elecko, M. Kaliciak, P. Straka, L. Škvarka, P. Šucha, D. Vass, A. Vozárová, J. Vozár 1989: Vysvetlivky ku geologickej mape juznej casti Východoslovenskej níziny a Zemplínskych vrchov (A guide for the geological map of the southern part of the East-Slovakian Plain and Zemplín Mountains), M=1:50 000. - Geol. ústav D. Štúra Bratislava, pp. 1-143. (In Slovakian.)

Bartha, A., P.U. Fügedi, L. Kuti 1987: Fiatal, laza üledékek mikrotápelem vizsgálata a Bodrogközben (Young, unconsolidated sediments in the Bodrogköz).- MÁFI Évi Jel. 1985-rôl, pp. 165-186, Budapest. (In Hungarian.)

Biely, A., V. Bezák, M. Elecko, P. Gross, M. Kaliciak, V. Konecný, J. Lexa, J. Mello, J. Nemcok, M. Potfaj, M. Rakús, D. Vass, J. Vozár, A. Vozárová 1996: Vysvetlivky ku geologickej mape Slovenska (A guide for the geological map of East-Slovakia), M=1:500 000. - MZP SR Geologická sluzba, Bratislava, pp. 1-77. (In Slovakian.)

Borsy, Z. 1953: A Bodrogköz felszínének kialakulása (Landscape evolution of the Bodrogköz). Földrajzi Értesítő, 1953. 2/3, pp. 409-418. (In Hungarian.) 
Borsy, Z., E. Félegyházi 1983: Evolution of the Network of Water Courses in the North-Eastern Part of the Great Hungarian Plain from the End of the Pleistocen to Our Days. - Quaternary studies in Poland, 4, pp. 115-124.

Boucek, B., A. Pribil 1959: O geologických pomerech Zemplínskeho pohorí na východném Slovensku (Geology of the Zemplín Mountains in East Slovakia). - Geol. Práce, Zošit 52, Geol. úst. D. Štúra, Bratislava, 185-222. (In Slovakian.)

Cvercko, J. 1977: Zlomy vo východoslovenskejneogénnej oblasti a jej tektogenetický vývoj. Kand. diz. Práca (Tectonic zones and tectonic evolution of the East-Slovakian Neogene area). - PhD thesis Nafta, PTZ, Michalovce (In Slovakian.)

Dobos, E., J. Kobza 2008: A Bodrogköz talajai. Élet a folyók között. A Bodrogköz tájhasználati monográfiája (Land-use monography of the Bodrogköz). - Miskolci Egyetem Kiadó, pp. 39-47. (In Hungarian.)

Fehér, A. ed. 1988: Bodrogköz. Ember-táj-mezőgazdaság (Human-land-agriculture). - Magyar Tudományos Akadémia Miskolci Akadémiai Bizottság Kiadványa, pp. 1-236. (In Hungarian.)

Földvári, A., L. Wallacher 1970: Lithology of the Quaternary in the environs Tokaj, Bodrogköz, NortEast Hungary. - Acta Geologica Hungarica, 14, pp. 369-386.

Grecula, P., K. Együd 1982: Litostratigrafia mladšieho paleozoika a spodného triasu Zemplínskych vrchov (Lithostratigraphy of the Paleozoic and Low Triassic sequences of the Zemplín Mountains). - Miner. Slovaca, 14/3, Bratislava, 221-239. (In Slovakian.)

Hegedûs, Gy. 1952: Jelentés az 1949. évi bodrogközi felvételről (Report on the geological mapping of the Bodrogköz in 1949). - A Magyar Állami Földtani Intézet Évi Jelentése 1949-rôl, pp. 177-180. (In Hungarian.)

Horniš, J. 1977: Sedimentárno-petrografická analýza kvartérnych sedimentov Východoslovenskej níziny. Manuskript (Sedimentological analyses of the Quaternary sediments of the EastSlovakian Plain. Manuscript). - Geol. úst. D. Štúra, Bratislava (In Slovakian.)

Jámbor, Á. 1998: A magyarországi kvarter (negyedidőszaki) képződmények rétegtanának áttekintése (A review of the stratigraphy of the Hungarian Quaternary formations). - In: Bérczi, István, Áron Jámbor (ed.): Magyarország geológiai képződményeinek rétegtana. A MOL RT és a MÁFI kiadása. pp. 495-517. (In Hungarian.)

Krippel, E. 1971: Postglaciálny vývoj vegetácie východného Slovenska (Evolution of the post-glacial vegetation in East-Slovakia). - Geogr. cas. Slov. Akad. Vied, 23/3, Bratislava, pp. 225-241. (In Slovakian.)

Lexa, J., V. Konecný, M. Kaliciak, V. Hojstricová 1993: Distribúcia vulkanitov karpatsko-panónskeho regiónu v priestore a case. - In: Rakús, M., J. Vozár (Ed.): Geodynamický vývoj a hlbinná stavba Západných Karpát (Spatial and temporal distribution of the Carpathian-Pannonian volcanites. - In: Rakús, M., J. Vozár (Ed): Geodynamic evolution and deep structure of the NorthCarpathians). Bratislava, Geol. úst. D. Štúra, pp. 57-70. (In Slovakian.)

Lozek, V. 1963: Výskum lozisek prirozených hnojiv na východným Slovensku (Research of the peat deposits in East-Slovakia). - Zpr. geol. výsk., Bratislava, pp. 346-348. (In Slovakian.)

Planderová, E., V. Sitár, P. Grecula, K. Együd 1981: Biostratigrafické zhodnotenie grafitických bridlíc Zemplínskeho ostrova (Biostratigraphic evaluation of the graphitic shales in the Zemplin Mountains). - Mineral. Slovaca, 13, Bratislava, pp. 97-128. (In Slovakian.)

Rónai, A. 1985: Az Alföld negyedidôszaki földtana (The Quaternary geology of the Great Hungarian Plain). - Geologica Hungarica Series Geologica, pp. 1-445. (In Hungarian.)

Schmidt, Z. 1974: Mäkkýše kvartéru juznej casti Východoslovenskej níziny. Manuskript (Quaternary Molluscae of the eastern part of the East-Slovakian Plain. Manuscript). - Geol. ústav D. Štúra, Bratislava (In Slovakian.)

Sümeghy, J. 1951: A Tisza szabályozás földtani viszonyai (Geological concerns of the regulation of the River Tisza). - MÁFI Évi jelentése az 1945-47-rôl (In Hungarian.)

Vaškovská, E. 1974: Litologická charakteristika kvartérnych piescitých sedimentov jv. casti Východoslovenskej níziny. Manuskript (Lithological characterization of the Quaternary sandy deposits in the south-eastern part of the East-Slovakian Plain. Manuscript). - Geol. úst. D. Štúra, Bratislava. (In Slovakian.) 